\title{
Implementation of Character Education Using Islamic Studies in Elementary School Teacher Training
}

\author{
$1^{\text {st }}$ Burhanuddin TR \\ Study program of Elementary \\ School Teacher Training \\ Universitas Pendidikan Indonesia \\ Bandung, Indonesia \\ burhanuddintr@upi.edu
}

\author{
$2^{\text {nd }}$ Nuur Wachid Abdul Majid \\ Study program of System and \\ Information Technology \\ Education \\ Universitas Pendidikan Indonesia \\ Bandung, Indonesia \\ nuurwachid@upi.edu
}

\author{
$3^{\text {rd }}$ Rizki Hikmawan \\ Study program of System and \\ Information Technology \\ Education \\ Universitas Pendidikan Indonesia \\ Bandung, Indonesia \\ hikmariz@upi.edu
}

\begin{abstract}
Government has been socializing of character education at recent times. One of the character values contained in Islamic education is taught in every class that every students must practice in daily activity. This research aims to know how to implement character education using Islamic studies in elementary school teacher training (PGSD). This research method is qualitative naturalistic using case study approach. The location of this research is PGSD UPI Purwakarta. Informants of this research are: (1) lecturers of Islamic Studies; and (2) Students of Elementary School Teacher Training. Data collection in this research using technique: (1) observation; (2) indepth interview; and (3) literature review. Data collection techniques using Miles and Huberman model, namely: data collection, display data, data condensation, and conclusions: drawing / verifying. The results of this study are: (1) character planting through Islamic religious learning is reflecting Siroh Nabawiyah (history of Prophet Muhammad) into daily life; (2) learning is using peer learning methods or Tutorial that the students are guided by the students up level to hone the character in accordance with Islamic values; (3) apply exemplary (uswah) methods to every classroom learning; and (4) lecturers were giving time to students for sharing or asking of anything.
\end{abstract}

Keywords- character education; Islamic studies; elementary school teacher training; uswah; peer learning.

\section{INTRODUCTION}

Indonesia is in decadence morally lately that is due to the lack of morality and emptiness of the soul in most people. One of the causes of corruption lifestyle and family life, community, nation and state is a sin Value for the Creator, Allah 'Azza wa Jalla. Society involved Creator and legalize in various ways. Education curriculum in Indonesia has never made education of faith the core of education curriculum. The wrong educational view chooses the positions of imamate education on various aspects.
The act of corruption has become a tradition and other crimes are part of the moral decadence itself.

One way to examine how life purpose affects academic learning is to assess the ways that purpose at the start of a course relate to desired outcomes of the course [1]. The goal in learning has a meaning for a student to know what targets should be achieved. The problems that occur in the students due to lack of guidance and attention from teachers. Counseling should be done maximally in order to produce students who are characterized in accordance with the national philosophy.

Chief of Regional Police of Yogyakarta, Ahmad Dofiri said that there are 43 criminal cases involving students, the data was collected from the beginning of the year until towards the end of 2016 [2]. In addition, according to KPAI (Commission on Child of Protection Indonesia), children did scuffle increased from 46 cases in 2014 to 103 cases in 2015 [3]. A student should be a useful and intelligent person in attitude, but in reality there is no difference between students and non-students. School is only a formality and get a diploma course, so ignore the moral values taught in school.

Actually the problem that arises is the influence of globalization and the rapid increase of information technology and massive. In addition, the economic gap is a factor that can increase the learning process in schools is less effective. Economic developments, the stance of teacher organizations, changes in the tax structure, shifts in patterns of occupational mobility, and the increase of dual-salary households are other factors that will determine the role of technology in instruction and the organization of the school system [4].

Character education becomes the basis of learning in schools, because the implementation of character 
for students should be given early on. The ethics of care can be seen as fundamentally relational, not individual-agent-based in the way of virtue ethics, and the ethics of care is more indirect than character education [5]. Mastery of character education can't be seen from the way students answer the question, but they can be seen from daily behavior. Implementation of character education is the daily attitude of a person that reflects the character itself, so habituation of a good attitude is the right step in the learning process.

Character can basically be formed by itself, but the process of habituation requires mentoring and social partners. The formation of student competence and its implementation can be achieved through the concept of social partnerships, as well as the competence obtained can be applied contextually [6]. Life together in social partnerships become the key to successful implementation of the process of character education in the community layer. Moreover, a student gets the opportunity to learn maximally in the class to be trained in applying her national character.

A teacher must master the characters that will be taught to the students. In the end the role of teachers is very important in shaping the character of students through the learning process. Character education planting requires a long process, because it is not obtained instantly. Teachers must be good at managing strategies to integrate learners' competencies, ranging from knowledge and skills to their field and national attitude.

Teaching is a moral profession, it is a vocation that demands both a deep personal commitment and clear, rational principles [7]. Being a teacher basically has a very high sincerity soul, so in the process of delivering learning materials can be easily absorbed by the students. The presence of a teacher to be an example for students in carrying out activities, it is no wonder the behavior of teachers can be followed by the students themselves.

University of education has a great opportunity in printing prospective educators who are professional and have national character. The characters must be mastered in theory and practice by the education practitioners, so it can be applied in their respective schools. The learning process at the university should prioritize the planting of the character's educational foundation and not just limited to theory. The student must have a broad view of the problems facing the Indonesian people, especially in moral decadence. The role of students to be creative and create changes in the future so that the moral of the nation's children must be addressed based on science and moral. Science and morals are an inseparable whole, so both must be implemented together. Education must involve knowledge and understanding and some kind of cognitive perspective, which are not inert [8].

In human character education, religious values, compassion, trust, togetherness, and philanthropy (learning to live together), and learning-to-be are not learned by means of lecture method and speech (learning to do), but through, acting, and various based on basic understanding (learning to know), and exemplary of adults, namely parents, principals, teachers and academic community including traders around the campus, and The Kyai and Ustadż in Pondok Pesantren and Majlis Taklim, as well as community leaders in the neighborhood.

Thus, the purpose of this study is to reveal how character education can be implemented through Islamic religious learning in primary school teacher education

\section{RESEARCH METHODOLOGY}

This research used qualitative naturalistic to find out how character education can be implemented through Islamic learning in elementary school teacher training. Case study research is a qualitative study that seeks to discover meaning, investigate processes, and gain insight and understanding of individuals, groups, or situations [9]. The research was located in Universitas Pendidikan Indonesia Purwakarta that is addressed on the $8^{\text {th }}$, Veteran Street Purwakarta. The time of this research is carried out approximately 3 month that is counted from September to December 2017.

The informants for this research are: (1) lecturers of Islamic studies; and (2) Students of Elementary School Teacher Training. Data collection techniques in this study used 3 ways, namely: (1) in-depth interview; (2) participatory observation; and (3) documents analysis. This data analysis are used by Miles, Huberman, \& Saldaña's interactive model.

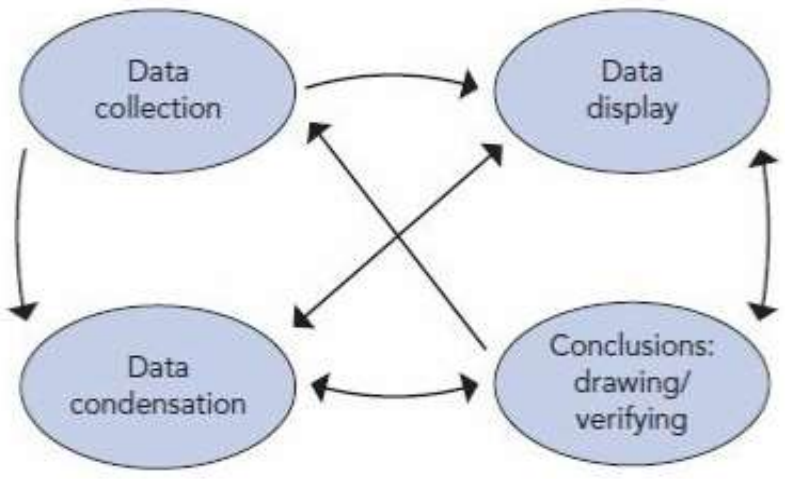

Figure 1. Data analysis components: Interactive Model [10]

\section{RESULT AND DISCUSSION}

Character education becomes the main foundation in every learning process. The emphasis of the material presented to the student must include comprehensively, namely: knowledge, skills, and personality (ethics). Education can produce a competent generation in its field and use that knowledge according to its place. Characteristic 
generations can change the usefulness they have for things that are useful.

Indonesia is a country that has a myriad of local wisdom and is implemented into the values of learning. A student not only learns science in general, but learns related to attitudes that are packaged in the planting of characters. The government is currently focusing on socializing character education as part of learning. Government target is the application of character education can already be felt in 2020 .

The Government seeks to implement the mandate of the Constitution of Article 31 and Law No. 20 of 2003 on the National Education System. In the law, the government paid attention to the concept of faith and piety and noble character as the ultimate foundation for realizing intelligent and competitive genera in the global world. Implementation of religious values in every learning is expected to be a strengthening on improving the character of students. Student characters can be well formed and can be practiced.

Religious education becomes one of the compulsory subjects that must be taken by the students. Laying the foundation of religion on students is expected to apply these values to everyday life. Indonesia is a country that has a principle of civilized, that is able to be good in accordance with the norms prevailing in this country. The strengthening of these national values becomes the main point in every lesson.

Primary school teachers are at the forefront of developing student attitudes, because at the elementary level the main gate of a student is to know the world. The behavior and attitudes of an elementary child is very influential in the formation of personality in the future. The role of teachers to form a personality with the values of national character is very fitting to be planted since they enter elementary school. Students are expected to have that character and can be applied in the global world.

The obstacles faced by educators today are the increasingly rapid influence of globalization affecting the behavior of the child itself. Children today have begun early maturation, because children have begun to follow the style of adults or other nations through the media. Thus the role of teachers to offset the influence of media hegemony that can damage the national character of children who are studying in elementary

\section{A. Character Planting through Islamic Religious Learning is Reflecting Siroh Nabawiyah (history of Prophet Muhammad) into Daily Life}

Siroh Nabawiyah or the history of the Prophet Muhammad's journey along with his Companions can be a lesson that can be taken wisdom. The cultivation of character values to the students is done by recounting some of the Prophet's history associated with learning. This method is very appropriate because the average student has the ease of remembering through the story. The planting of characters through the story method is expected to seep into the subconscious of learners.

Siroh nabawiyah is a series of journey of life of the prophet that is reflected to the daily activities. This reflection can be attributed to learning based on an exemplary person. The reflection of the nature and life of Prophet Muhammad on the daily life of the students is part of the reflection of the character that must be improved. These characters become part of the national values and become part of the culture of Indonesian citizens.

The story of the Ambiya or the Prophets and the Companions can be the foundation of a daily attitude. The story has a profound meaning and becomes a learning for students to be able to apply, especially in elementary school. The average age of elementary school children is more accepting of story-based material, so the ability to tell the story given by the teacher is the main part. The storytelling skills must be mastered by prospective elementary school teachers and need to be trained while at the university.

Islamic education can essentially produce a noble human and practice it in life. Amalus solikhah becomes a key aspect that must be practiced and disseminated to the society, so it is expected to create baldatun toyibatun warobbul ghoffur. The orientation of the Islamic Religion Education is the formation of amalus solikhah values in addition to Islamology in which the affective aspect is more dominant than the cognitive aspect with an orientation to the formation of individual and social piety [11].

\section{B. Learning is using Peer Learning Methods or Tutorial that the students are Guided by the Students up Level to Hone the Character in Accordance with Islamic Values}

Universitas Pendidikan Indonesia has a method of learning by involving peers. One of the subjects that involves peers is Islamic Religious Education. Both courses involve students who have passed the course of Islamic Religious Education and have followed the selection to become tutors. Tutorial is the name of student coaching activities that are following the course of Islamic religious education. Tutorial activities become very important to foster student attitude to have national character.

Tutorials become legal activities and get permission from UPI Leaders. In addition Tutorial becomes the assistance of the course of Islamic Religious Education by involving students directly. Lecturers of Islamic Religious Education usually work together with the Da'wah Institution of Campus (LDK) to assist in the implementation of the assistance or the Tutorial. 
Tutorials are conducted in semesters 1 and 2 with various programs to foster religious values for prospective educators. Some methods applied include: religious dialogue, religious lectures by inviting Mubaligh or Ustadz, and assistance. The combination of coaching done by lecturers through Religious Education materials and coaching done by tutors or peers is expected to increase competence on religious aspect. Understanding of Islam is also balanced with the attitude that reflects the religious man. The planting of the characters is obtained through PAI Tutorial learning.

The results of the programs held on campus are expected to have a significant impact. Students can apply the meaning of culture and religion in everyday life. The values of culture and religion are required as foundation in order to face the competition of consumerism and also be able to face a reasonable life [12].

\section{Apply Exemplary (Uswah) Methods to Every Classroom Learning}

The character of a student is usually influenced by the character of the teacher, so that the things done by the teacher can be easily imitated by the students. The process of impersonation by students takes a very long time, although in reality students can see firsthand what a teacher does. The process of imitation is done unconsciously and on the result will directly impact. So that good or bad behavior of student usually influenced by teacher factor.

Implementation of exemplary always done maximally in order to produce competent student. Exemplary behavior of teachers when talking or delivering material, how teachers tolerate, and various other related matters [13]. This attitude must be mastered by the students in university, because it becomes an example for students later when teaching in elementary school.

Uswah Methods can be applied by everyone, including lecturers within the University. Implementation of this method can eventually be adopted by students to nurture elementary students later. University as a place to foster teacher candidates must also be able to apply the model to become role models of students in the world of work.

Habituation of good behavior or become a civilized educator must be trained in college, so when plunged in the field can be practiced without any obstacles or have been accustomed. Teachers are figures who should be role models and modeled by students of all aspects, both behavior, words, deeds, and how to speak. Students will tend to imitate deeds or behaviors as the teacher did.

\section{Lecturers were Giving Time to Students for Sharing or Asking of Anything}

A teacher should make time for sharing or listening to student complaints about their problems. Every student has a problem and not everyone can provide a solution or listen to a story about the problem students are facing up to now. Although in recent phenomena, teachers rarely provide a special place for students to tell their problems and provide the best solutions to students. Giving the solution is part of the education process so that children feel cared for and not fall into the wrong behavior.

The teacher is the second parent because the teacher's existence becomes a substitute for parents. Parents become a place to devote all the problems and as a place to solve student problems. Familiarize the process of discussion and provide a place to solve student problems on campus, is expected to foster the habit to the students. Lecturers in UPI Purwakarta always provide a place for students to share various things, such as academic problems, family problems, and other problems.

The process of guidance and sharing to students is expected to reduce the action of radicalism that began to bloom. Lecturers can provide advice on the problems faced by students, so as to reduce or lighten the student's burden. In the 21 st century, people experienced a radical transition that is the triumph of modernity that has reached all over the world marked by technological progress and science [14].

\section{SUMMARY}

The results of this study are: (1) character planting through Islamic religious learning is reflecting siroh nabawiyah (history of Prophet Muhammad) into daily life; (2) learning is using peer learning methods or Tutorial that the students are guided by the students up level to hone the character in accordance with Islamic values; (3) apply exemplary (uswah) methods to every classroom learning; and (4) lecturers were giving time to students for sharing or asking of anything.

\section{REFERENCES}

S. Moran, "Purpose-in-action education: Introduction and implications," J. Moral Educ., vol. 47, no. 2, pp. 145158, 2018.

[2] B. Kurniawan, "Kapolda DIY: Sepanjang 2016, 43 Kasus Kriminal Didominasi Pelajar," https://news.detik.com/berita/d-3382743/kapolda-diysepanjang-2016-43-kasus-kriminal-didominasi-pelajar, 2016.

[3] F. Maskur, "CATATAN AKHIR TAHUN KPAI: Anak Sebagai Pelaku Kejahatan Meningkat," http://lifestyle.bisnis.com/read/20160102/236/506440/cat atan-akhir-tahun-kpai-anak-sebagai-pelaku-kejahatanmeningkat, 2016.

[4] H.S.Broudy, "Technology and educational values," in Ethics and Educational Policy, K. A.Strike and K. Egan, Eds. New York: Routledge, 2010.

[5] N. Noddings, Educating moral people: A caring 
alternative to character education. Teachers College Press, PO Box 20, Williston, VT 05495-0020, 2002.

[6] N. W. A. Majid and P. Sudira, "Proses perolehan kompetensi TIK melalui program praktik industri siswa SMKN 2 Pengasih Kulon Progo," J. Pendidik. Vokasi, vol. 7, no. 1, pp. 14-29, 2017.

[7] I. Rissanen, E. Kuusisto, E. Hanhimäki, and K. Tirri, "The implications of teachers' implicit theories for moral education: A case study from Finland," J. Moral Educ., vol. 47, no. 1, pp. 63-77, 2018.

[8] P. Fitzsimons, Nietzsche, Ethics and Education: An Account of Difference. Rotterdam: Sense Publishers, 2007.

[9] Emzir, Metode penelitian kualitatif: analisis data. Jakarta: Rajawali Pers, 2010.

[10] M. B. Miles, A. M. Huberman, and J. Saldaña, Qualitative data analysis: A methods sourcebook, 3rd ed.
New York: SAGE Publications, Inc., 2014.

[11] Sunhaji, "The Implementation of Integrated Learning in the Islamic Religion Education as to Grow the Religiosity and Faith of Learners," Int. J. Humanit. Soc. Sci., vol. 6, no. 11, pp. 279-289, 2016.

[12] H. Indra, "Islamic Religious Education in The Era of AFTA," Tarbiya J. Educ. Muslim Soc., vol. 2, no. 2, pp. 204-221, 2015

[13] Azamiyah, "Konsep Pendidikan Karakter dalam AlQur'an Surah Al Hujurat; 11-13," Tadarus J. Pendidik. Islam, vol. 6, no. 1, 2017.

[14] A. Qodir, Dakir, and Umiarso, "The Concept of Human Unity and Islamic Inclusive Education: A Study of KH. Imam Zarkasyi's Thought in Social Change," J. Islam. Stud. Cult., vol. 5, no. 2, pp. 47-56, 2017. 